ISSN No. 0974-035X

\title{
EXPLORING MOBILE AS LANGUAGE LEARNING LAB FOR SECOND LANGUAGE LEARNERS
}

\author{
Prof. Dr. Jagdish Joshi \\ Mr.Tapan P.Shah
}

\begin{abstract}
:
This paper portrays the structure and improvement of a Mobile language lab system called MLab. The Mobile Lab structure hopes to displace the customary language lab which commonly has a prohibitive plan and needs correspondence with an all the more straight forward, minimal effort versatile language lab. The Mobile Lab is profitable to language teachers and Students, and the system offers them the chance to move around and use their very own contraptions at whatever point and in wherever. The Mobile Lab system has been made by using a couple of web developments to give a snappy and profitable technique for getting to required substance.
\end{abstract}

Keywords: Mobile Language Lab, Language Teaching, Web Technologies, Techniques 


\section{Introduction}

Language labs, which can be characterized as sound or varying media hardware that is utilized to encourage language educating and learning, have been around since the 1950s and have experienced a few phases of improvement. The early kinds of language labs comprised of a recording device and audiocassettes, which were utilized to educate students' elocution and to build up their listening abilities. This ordinary lab was later moved up to a lingua phone lab, in which every student was furnished with a headset to empower the person in question to tune in to the audiotapes separately [Roby, 04; Salaberry, 01].

In any case, these labs before long ended up disliked due temperamental innovation and an absence of suitable preparing to the two instructors and students. Moreover, these labs were connected with the behaviorist model, which established in the audio-lingual ways to deal with language. By the late 1970s, another age of language labs showed up alongside the approach of PCs. PC labs started to bit by bit supplant Audio language labs, and they offered more prominent innovative headways and that's only the tip of the iceberg learning and instructing choices. In contrast to the past age of language labs, which were given exclusively to tuning in and talking aptitudes, the new computerized labs can encourage the educating of perusing and composing. During the $1980 \mathrm{~s}$, the term CALL, which represents PC helped language learning, turned into a popular expression in language educating and learning, and there was a whirlwind of language learning programming furthermore, CALL distributions. After 10 years, with the rise of the Internet, most customary PC labs were supplanted by system and sight and sound empowered frameworks with broadened usefulness, in this manner enabling students to record, see, transfer, and download sight and sound (for an exhaustive diagram of the historical backdrop of labs, [see Roby, 04 and Remenyi, 07]. Numerous specialists have called attention to the effect of the present language labs on language educating and learning. With respect to language students, these labs can be utilized successfully to evaluate their discourse, improve their elocution by giving a few tests of voices and accents, encourage their correspondence, improve their tuning in aptitudes, and improve their 
familiarity by giving real learning materials. Another bit of scope of language labs is that they decrease timid students' uneasiness by offering them some level of security and guaranteeing their secrecy using stalls and headsets. On the other hand, numerous specialists accept that language labs have their inadequacies.

As per Bräuer [01], for example, "the term labs these days likewise triggers recollections about a spot where students vanish behind innovation, isolated from one another, digging straight into the electronic condition and battling a solitary fight with semantic solicitations from puzzling specialists" [p. 185, refered to in Roby, 04].

Indeed, Bräuer's perspective on language labs proposes an absence of cooperation, which is a key component in second language (L2) procurement. As indicated by Ellis $[99$, p. 1], association alludes to "the social conduct that happens when one individual speaks with another." Interaction in the L2 homeroom furnishes students with fitting, intelligible info while giving them chances to arrange meaning, which, thus, encourages L2 learning [Long, 90]. The issue with the customary lab format and corner size is that they are to some degree prohibitive, in this way neglecting to give satisfactory workspaces and the opportunity to move around or work in gatherings.

Most instructors and students might not have the imperative PC aptitudes and may before long become overpowered by the advanced usefulness of the present computerized lab frameworks. Along these lines, they ought to be furnished with the proper preparing and specialized help to decrease the dread that is normally connected with new innovation. Repetitive specialized issues are another weakness. The inability to work the lab gear proficiently because of equipment or programming issues will unavoidably cause delays and disappointment for the two students and educators.

To conquer such issues in existing language labs, this paper will center to introduce versatile to language learning. This framework, which is called MLab, is simple to utilize and depends on web advancements. MLab is likewise a cross-stage framework, which 
implies that it can work on any cell phone with an Internet connection. It depicts how our framework will add to the past work attempting to conquer any hindrance between the headways of new advances and the elements of language labs.

Over the previous decade, Mobile innovations have been getting broad consideration inside the field of language instructing and learning. This is proving by the expanding number of distributions that talk about their potential as an instructive apparatus [see Kukulska-Hulme and Traxler, 05; Traxler, 07; Ally, 09; Yang et al., 05].

As indicated by Khanna and Singh [11], cell phones are recognized as a conveyance channel with colossal potential for manageable learning and that offers better availability and practicability. Albeit versatile advances incorporate tablets, MP3players, iPods, and individual computerized collaborators (PDAs), cell phones are picking up energy and are pulling in expanding consideration from analysts [see Gilgen, 04; Koole, 09; Stockwell, 10; Yamada et al., 01; Mehta, 13; among numerous others]. Numerous analysts contend that the ubiquity of cell phones is ascribed to a few elements, one of which is the moderately minimal effort of these gadgets [Pea and Maldonado, 06; Crowe, 07; Shin et al., 07]. This shows there is no requirement for educators or foundations to furnish students with refined, extravagant hardware or establishments to empower the coordination of Mobile Assisted language learning (MALL) into their instructing condition. Another interesting component of cell phones is that they can be connected to what Koole [09: p. 36] alludes to as "the mental solace."

She proposes that "very versatile, instinctive, and straightforward gadgets can lessen psychological burden and increment task fulfillment rates on the grounds that the student can focus on the errands as opposed to the devices." This element can diminish students' nervousness and improve their dimensions of solace what's more, inspiration. Likewise, Peters [07] proposes that cell phones can empower omnipresent learning in both formal and casual settings by lessening students' dependence on specific work and study settings. This whenever, wherever highlight can't be found in customary language or PC 
labs. As far as intuitiveness, thought about to MP3s or iPods, most present day cell phones consolidate email and short message administration (SMS) capacities. Such highlights furnish the two students and educators with chances to communicate effectively. Perusing usefulness is another preferred position that enables students to access refreshed or explicit data when required. As indicated by Yang et al. [05: p. 20], the universal and multifunctional nature of the present cell phones go past customary oral correspondence. The new innovation gives clients the capacity to get to the Internet to scan for data, trade email messages or SMS, read or tune in to books on the web, make and offer interactive media, and even shop on the web.

A few impromptu MALL applications that served specific language adapting needs; and, at long last, we examine MALL frameworks that utilized informal organizations alongside Mobile language labs.

\section{Short Message Service System}

A standout amongst the most well known procedures utilized in MALL frameworks is the Short Message Service (SMS). This component enables students to get various new English words every day, which, in turn, upgrades their vocabulary and punctuation. Different investigations, for example, those directed by Cavus and Ibrahim, Kennedy and Levy, and Alemi et al. have demonstrated the adequacy of utilizing SMS in English learning and have shown that students incline toward the utilization of cell phones in the learning cycle.

Cavus and Ibrahim planned a framework that put away the two students' numbers and a document comprising of a rundown of new English vocabulary words. The framework sends 16 messages day by day over an eight-hour time frame in the first part of the day, and the students can peruse the messages whenever it might suit them. The assessment of the framework uncovered that the students delighted in the new technique for learning English vocabulary and saw it as helpful. 
Likewise, Kennedy and Levy announced their involvement in sending one vocabulary-, syntax, or course-related message over a seven-week time span to 76 Italian novice students of English. The students valued the utilization of versatile telephones and the manner by which the experience urged them to learn outside of the study classroom setting. On the other hand, Alemi et al. looked at the utilization of SMS and the lexicon for learning English vocabulary. Forty-five first year recruit students were considered for about four months. Of these students, 28 utilized SMS and the rest of a word reference. The post-test results demonstrated that the utilization of SMS had an increasingly noteworthy impact on students' vocabulary maintenance than the utilization of the lexicon. This shows the utilization of SMS helped students to hold vocabulary in their long haul memory.

\section{MALL applications}

Huang and Sun, analysts at the National Kaohsiung Normal University in Taiwan, structured and built up an English listening exercise framework that permits students to take an interest in English listening practices whenever. The framework comprises of two subsystems: the first is a site for interactive media materials that is mindful for transferring and overseeing sound and video listening materials, and the second is a versatile sight and sound English listening exercise subsystem that enables the students to play and complete activities identified with English listening materials. The framework too offers various numerous administrations, for example, the arrangement of web based listening materials, which students can download to their cell phones and after that play while they are disconnected. It likewise enables the students to compose their listening materials and talk about them with their schoolmates by means of a $Q \& A$ informing board. With respect to content, the listening materials are separated into five dimensions-simple, simple, ordinary, hard, and hard-to assist the students with choosing the most reasonable material. 


\section{Social networks}

The utilization of Social networks connected to cell phones for English language learning has step by step increased. Twitter was delegated a standout amongst the most effective and persuasive instruments for English perusing, composing, and communication. Social Media is a proficient device for encouraging open and social skill. The information examination demonstrates that the students concentrated on substance instead of sentence structure while drafting messaging. Many students utilize Social Media to trade materials and participate in gathering discussions. Kabilan et al. and Al-Shehri examined students' utilization of Facebook as an English-learning apparatus. The students utilized Facebook to trade video and sound English materials, just as to convey and have discourses utilizing the English language. The outcomes demonstrate that most students acknowledged Face book and discovered it a helpful and important learning condition.

\section{Mobile language labs}

Picking language labs or study classroom preparing systems is the best choice made by language instructive establishments to offer their students the capacity to learn English or even a few dialects at once. The language lab is an extremely valuable device that encourages study classroom commitment and cooperation by means of PC based activities and exercises to amplify language drenching. These labs give an altogether different encounter from the customary arrangement of educating and learning dialects, offering further developed highlights and functionalities. A language lab is handy learning another dialect just by contemplating the hypothesis isn't sufficient to ensure a fruitful language learning knowledge. Language labs give practice in an engaging and intuitive manner to get the 4 principle language aptitudes: tuning in, talking, perusing, and composing. Students adapt all the more thoroughly through a language lab, utilizing more class time rather to accomplish these three primary targets: 
Using a Mobile language lab has many benefits

Self-learning: The student advances in an independently directed however, organized and dynamic preparing to accomplish the objectives and target set by the school or instructive body.

Complimentary: Language labs enable students to strengthen material learned from anywhere by placing them into training through intelligent exercises.

Checking and Evaluation: Teachers know the advancement of every student and get reports of qualities and shortcomings to all the more likely adjust the study classroom exercises.

Students adapt a lot quicker in the Mobile language lab Practice prompts language learning achievement Language labs' intuitive courses help students adapt a lot quicker than in a standard homeroom setting. The technique of the study all language system utilizes a dynamic model to advance characteristic realizing, where students become familiar with the various ideas of language in a natural way. The language lab helps the inspiration of students accomplishing larger amounts of language maintenance and advancement.

\section{The educator takes on an increasingly significant job in the language lab}

There is a major dread in the instruction world that innovation will supplant the job of the instructor and the position will wind up out of date completely. The language lab exposes this legend since it gives beneficial materials that just encourage the job of the educator as opposed to contend with it. The instructor would then be able to concentrate on the significant pieces of the course as opposed to sit around idly clarifying everything. The structure of the language lab courses additionally encourage the work educator puts in when getting ready exercises and enables them to set them up in less time and with a more noteworthy volume of intelligent assets. 


\section{Use a larger number of assets and changed exercises}

Language labs enable students to rehearse the language with an a lot more extensive assortment of exercises and activities dependent on the PC. Learning happens in an organized manner, in a genuine setting and outwardly appealing way that inundates the student in the language learning condition and advances language use. The students can watch recordings, practice their articulation through a discourse recognizer, adapt new vocabulary, and considerably more.

\section{Language labs consider as decent variety}

Language research facilities give educator regard for students, particularly on account of schools with various dimensions in light of the fact that as intelligent courses, language labs are custom-made to the individual needs of students. Then again, because of observing and assessment continuously, the instructor knows precisely what course goals posture real classroom manages for the student time and can fortify the class as needs be.

\section{Labs encourage correspondence}

Language labs empower correspondence student instructor just as student with exercises and activities fundamental to oral correspondence and the comprehension of the language. The labs incorporate apparatuses for making gatherings, have discussions by means of talk, advance messages on the board, access to a network of students who are additionally concentrating a similar language, and so forth.

\section{Language labs are an instinctive device for both the student and educator}

This strategy for learning does not require proficient specialized aptitudes for use. The educator just needs fundamental PC abilities and students will respect the additional innovation they are as of now so capable with. 


\section{Language labs improve figuring assets}

The two colleges and universities have study classrooms with PCs there for students to finish school works or concentrate different subjects. There are likewise various workforce PC labs or office PCs for organization additionally accessible. Language labs basically reuse assets an instructive organization as of now has and adjusts it to the language course.

To put it plainly, language labs are an exceptionally far reaching and financially savvy apparatus for instructive establishments to adapt their language preparing and furthermore offer students successful language learning by means of the most recent innovation and instructive substance. They are the ideal answer for planning organized scholastic educational programs as per the goals of an instructive focus with a universal work group of spectators that looks for the most noteworthy quality in instructing. 


\section{Works Cited}

Alemi, Minoo, Mohammad Reza Anani Sarab, and Zahra Lari.“Successful Learning of Academic Word List via MALL" Mobile-Assisted Language Learning. International Education Studies 5(6) .2012. 99.

Ally, Mohame. Mobile Learning: Transforming the Delivery of Education and Training. Athabasca University Press .2009

Al-Shehri, S.: "Context in Our Pockets: Mobile Phones and Social Networking as Tools of Contextualising Language Learning". In 10th World Conference on Mobile and Contextual Learning, Beijing, 2011

Alotaibi H. M., Alamer R. A., Al-Khalifa H.S. MLab: A Mobile Language Cavus, N., and Dogan I. "M-Learning: An Experiment in Using SMS to Support Learning New English Language Words". British Journal of Educational Technology 40(1) .2009, 78-91.

Bräuer, G. "Language learning Centers: Bridging the Gap between High School and College." In G. Bräuer (Ed.), Pedagogy of Language Learning in Higher Education: An Introduction, 2001, 185-192. Westport. 12/04/2019.

Demouy, V., Eardley, A., Shrestha, P., and Kukulska-Hulme, A."The Interactive Oral Assessment (IOA) Project: Using Talkback for Practice and Assessment of Listening and Speaking Skills in Languages". In Proceedings of the 14th International Conference on Interactive Collaborative Learning (ICL) .2011, 126129 
Kabilan, M.K., Ahmad, N. and Abidin, M.J.Z. "Facebook: An Online Environment for Learning of English in Institutions of Higher Education?" The Internet and Higher Education, 13(4). Special Issue on Web 2.0, 2010, 179-187.

Kennedy, C. and Levy, M. 'L'italiano Al Telefonino: Using SMS to Support Beginners' Language Learning". ReCALL 20(3), 2008, 315-330.

Kukulska.Hulme, A. and Traxler, J. Mobile Learning: A Handbook for Educators and Trainers. Psychology Press. 2005.

Long, M. "The Role of the Linguistic Environment in Second Language Acquisition" In W. Ritchie and T. Bhatia (eds.), Handbook of Second Language Acquisition, 413-468. San Diego: Academic Press. 1996.

Panziera, L., Comerio, M., Palmonari, M., De Paoli, F. and Batini, C. "Quality-Driven Extraction, Fusion and Matchmaking of Semantic Web API Descriptions". Journal of Web Engineering, 11(3), 2012.

Pea, R.D., and Maldonado, H. "WILD for Learning:Interacting through New Computing Devices Anytime, Anywhere". The Cambridge Handbook of the Learning Sciences, 852-886.2006.

Pemberton, L., Winter, M. and Fallahkhair, S. "Collaborative Mobile Knowledge Sharing for Language Learners". Journal of the Research Center for Educational Technology 6(1), 144-148.2010.

Salaberry, M.R. "The Use of Technology for Second Language Learning and Teaching: A Retrospective". The Modern Language Journal 85(1) 39-56, 2001. 


\author{
Prof. Dr. Jagdish Joshi \\ Professor-Director \\ UGC-Human Resource Development Centre, \\ Ahmedabad \\ \& \\ Mr. Tapan P. Shah \\ Ph.D Research Scholar, Gujarat University,Ahmedabad \\ Assistant Prof. Aroma College of Commerce \\ Usmanpura, Ahmedabad. \\ tpnshah87@gmail.com
}

